\title{
Microwave-Assisted Synthesis and Characterization of Certain Oximes, Hydrazones, and Olefins Derived from $\beta$-Keto Sulfones
}

\author{
Hatem A. Abdel-Aziz, ${ }^{1,2}$ Hazem A. Ghabbour, ${ }^{1}$ Mashooq A. Bhat, ${ }^{1}$ and Hoong-Kun Fun ${ }^{1,3}$ \\ ${ }^{1}$ Department of Pharmaceutical Chemistry, College of Pharmacy, King Saud University, P.O. Box 2457, Riyadh 11451, Saudi Arabia \\ ${ }^{2}$ Department of Applied Organic Chemistry, National Research Center, Dokki, Cairo 12622, Egypt \\ ${ }^{3}$ X-Ray Crystallography Unit, School of Physics, Universiti Sains Malaysia (USM), 11800 Penang, Malaysia
}

Correspondence should be addressed to Hatem A. Abdel-Aziz; hatem_741@yahoo.com

Received 3 June 2014; Revised 18 August 2014; Accepted 6 September 2014; Published 16 September 2014

Academic Editor: Hakan Arslan

Copyright (C) 2014 Hatem A. Abdel-Aziz et al. This is an open access article distributed under the Creative Commons Attribution License, which permits unrestricted use, distribution, and reproduction in any medium, provided the original work is properly cited.

\begin{abstract}
A new series of $\beta$-keto sulfone derivatives containing oximes $\mathbf{4 a - e}$, hydrazones $\mathbf{5 a}, \mathbf{b}$, and chalcones $\mathbf{7 a}-\mathbf{d}$ were prepared using microwave irradiation (MWI) by the reaction of $\beta$-keto sulfones 3 with hydroxyl amine, hydrazines, and aromatic aldehydes, respectively. The comparative study between microwave irradiation and conventional syntheses showed that MWI is effective in the synthesis of the title compounds through shortening of the reaction time and improvements in their yields. The structures of the synthesized compounds were established under the basis of their spectral data and X-ray single crystal analysis of compound $\mathbf{5 a}$. The crystal of 5a belongs to triclinic space group $P-1$, with $a=5.7735$ (2) $\AA, b=9.3224$ (3) $\AA, c=13.1696$ (5) $\AA, \alpha=76.411(1)^{\circ}$, $\beta=89.571(1)^{\circ}, \gamma=79.9380(9)^{\circ}, Z=2, V=677.97(4) \AA^{3}, D c=1.513 \mathrm{Mg} \mathrm{m}^{-3}, \mu=0.44 \mathrm{~mm}^{-1}, F(000)=320, R=0.026$, and $w R=0.070$ for 2690 observed reflections with $I>2 \sigma(I)$.
\end{abstract}

\section{Introduction}

Over the past few years, sulfone derivatives have attracted considerable attention due to their broad spectrum of biological activities $[1,2]$ and for their great importance in organic chemistry $[3,4]$. Among the derivatives of sulfones, special attention has been drawn to the construction and reactivity of $\beta$-keto sulfones [5-9]. Some $\beta$-keto sulfones have been reported as effective antimicrobial agents against $S$. aureus and C. tropicalis [10]. Moreover, $\beta$-keto sulfones have been reported as selective inhibitors of $11 \beta$-hydroxysteroid dehydrogenase type I $[11,12]$. $\beta$-Keto sulfones are key starting materials in the synthesis of several biologically active compounds; for example, $\beta$-keto sulfones was used in the preparation of fused pyrimidine derivatives as potent AuroraA kinase inhibitors [13] and they were used also in the preparation of novel celecoxib analogs as potent anti-inflammatory agents [14]. Moreover, oxime derivatives showed a wide range of biological activity such as antifungal [15] and anticonvulsant [16] activities in addition to their antibacterial activity against multidrug resistant bacteria [17]. Hydrazone function is an important part in compounds with antibacterial activity [18] and with activity against methicillin-resistant Staphylococcus aureus [19]. Olefin derivatives have exhibited antibacterial activity [1] in addition to their antiplasmodial activity when combined with sulfone function [2].

In the light of previous data and in continuation of our interests in synthetic organic chemistry [14, 20-22], we report herein the microwave-assisted syntheexhibited the signal of the $\mathrm{NH}$ group atsis of some new oximes $4 \mathbf{a}-\mathbf{e}$, hydrazones $\mathbf{5 a}$, b, and olefins $7 \mathbf{a}-\mathbf{d}$ derived from $\beta$-keto sulfones derivatives.

\section{Experimental}

\subsection{Chemistry}

2.1.1. General. Melting points were determined on a Gallenkamp melting point apparatus and are uncorrected. Infrared (IR) spectra were recorded as $\mathrm{KBr}$ disks using the Perkin Elmer FT-IR Spectrum BX apparatus. NMR spectra were scanned in DMSO- $d_{6}$ or $\mathrm{CDCl}_{3}$ on a Bruker NMR spectrometer operating at $500 \mathrm{MHz}$ for ${ }^{1} \mathrm{H}$ and $125 \mathrm{MHz}$ for ${ }^{13} \mathrm{C}$. Chemical shifts are expressed in $\delta$-values (ppm) 
relative to TMS as an internal standard. Coupling constants $(J)$ are expressed in $\mathrm{Hz} . \mathrm{D}_{2} \mathrm{O}$ was added to confirm the exchangeable protons. The mass spectra were performed using a Varian MAT CH-5 spectrometer $(70 \mathrm{eV})$ or on an Agilent Triple Quadrupole 6410 QQQ LC/MS equipped with an ESI (electrospray ionization) source. The microwave irradiations were carried out in an Explorer-48 microwave reactor from CEM, USA.

2.1.2. Synthesis of 1-Aryl-2-arylsulfonyl Ethanones 3. These compounds were prepared according to the reported method [23].

\subsubsection{Synthesis of 1-(Aryl)-2-(arylsulfonyl)ethanone Oximes $\mathbf{4 a - e}$}

MWI Synthesis. A mixture of the appropriate sulfone 3 ( $1 \mathrm{mmol})$ and hydroxylamine hydrochloride $(0.11 \mathrm{~g}$, $1.5 \mathrm{mmol})$ and anhydrous sodium acetate $(0.12 \mathrm{~g}, 1.5 \mathrm{mmol})$ in ethanol $(5 \mathrm{~mL})$ was added to a closed vessel in a microwave reactor. The closed vessel was irradiated with microwaves at $100 \mathrm{~W}$ and $90^{\circ} \mathrm{C}$, with $200 \mathrm{psi}$ maximum pressure for 2 min (holding time). The vessel was cooled and the solid that formed was collected by filtration and washed with water, dried, and finally recrystallized from EtOH to afford compounds $4 a-e$, respectively, in $80-88 \%$ yields.

Conventional Synthesis. A mixture of the appropriate sulfone 3 (10 mmol), hydroxylamine hydrochloride $(1.1 \mathrm{~g}, 15 \mathrm{mmol})$, and anhydrous sodium acetate $(1.2 \mathrm{~g}, 15 \mathrm{mmol})$ in ethanol $(50 \mathrm{~mL})$ was refluxed for $1 \mathrm{~h}$ and then left to cool. The reaction mixture was poured into cold water and the solid product was filtered off, washed with water, and dried. Recrystallized from EtOH afforded $4 a-e$ in $54-70 \%$ yields.

(1)1-(4-Methoxyphenyl)-2-(phenylsulfonyl)ethanone Oxime (4a). Yield (75\%); m.p. 148-150 ${ }^{\circ}$ C; IR v $3250(\mathrm{OH}) \mathrm{cm}^{-1}$; ${ }^{1} \mathrm{H} \mathrm{NMR}\left(\mathrm{CDCl}_{3}\right) \delta 3.79\left(\mathrm{~s}, 3 \mathrm{H}, \mathrm{OCH}_{3}\right), 4.65$ (s, 2, $\left.\mathrm{CH}_{2}\right)$, $6.80(\mathrm{~d}, J=9.0 \mathrm{~Hz}, 2 \mathrm{H}, \mathrm{ArH}), 7.38-7.42(\mathrm{~m}, 2 \mathrm{H}, \mathrm{ArHs})$, 7.51-7.54 (m, 3H, ArH), 7.77 (d, $J=8.0 \mathrm{~Hz}, 2 \mathrm{H}, \mathrm{ArH}), 11.92$ (s, $\mathrm{D}_{2} \mathrm{O}$ exchangeable, $\left.1 \mathrm{H}, \mathrm{OH}\right) ;{ }^{13} \mathrm{C} \mathrm{NMR}\left(\mathrm{CDCl}_{3}\right) \delta 52.70$ $\left(-\mathrm{OCH}_{3}\right), 55.38\left(-\mathrm{CH}_{2}\right), 112.10,114.09,125.89,127.33,128.19$, $128.47,128.86,128.94,131.32,133.99,139.47,147.53$; MS (EI) $\mathrm{m} / z 305[\mathrm{M}]^{+}$.

(2) 1-(4-Chlorophenyl)-2-(phenylsulfonyl)ethanone Oxime (4b). Yield (88\%); m.p. $153-155^{\circ} \mathrm{C}$; IR $v 3270(\mathrm{OH}) \mathrm{cm}^{-1} ;{ }^{1} \mathrm{H}$ NMR $\left(\mathrm{CDCl}_{3}\right) \delta 4.27\left(\mathrm{~s}, 2, \mathrm{CH}_{2}\right), 7.26(\mathrm{~d}, J=8.5 \mathrm{~Hz}, 2 \mathrm{H}, \mathrm{ArH}), 7.40-$ 7.43 (m, 2H, ArH), 7.52-7.56 (m, 3H, ArH), 7.77 (d, $J=7.5 \mathrm{~Hz}$, $2 \mathrm{H}, \mathrm{ArH}), 11.91$ (s, $\mathrm{D}_{2} \mathrm{O}$ exchangeable, $\left.1 \mathrm{H}, \mathrm{OH}\right) ;{ }^{13} \mathrm{C} \mathrm{NMR}$ $\left(\mathrm{CDCl}_{3}\right) \delta 52.46\left(-\mathrm{CH}_{2}\right), 127.95,128.45,128.57,128.86,128.95$, 129.17, 132.00, 133.99, 136.19, 139.34, 147.05; MS (EI) $m / z 309$ $[\mathrm{M}]^{+}$.

(3) 1-(Naphthalen-2-yl)-2-(phenylsulfonyl)ethanone Oxime(4c). Yield (80\%); m.p. $138-140^{\circ}$ C; IR v 3248-2942 (OH) $\mathrm{cm}^{-1}$; ${ }^{1} \mathrm{H}$ NMR $\left(\mathrm{DSMO}-d_{6}\right) \delta 5.09\left(\mathrm{~s}, 2 \mathrm{H}, \mathrm{CH}_{2}\right), 7.53-7.56(\mathrm{~m}, 4 \mathrm{H}$,
ArH), 7.64-7.67 (m, 1H, ArH), 7.79-7.80 (m, 2H, ArH), 7.83$7.93(\mathrm{~m}, 4 \mathrm{H}, \mathrm{ArH}), 8.14$ (s, 1H, ArH), 11.91 (s, $\mathrm{D}_{2} \mathrm{O}$ exchangeable, $1 \mathrm{H}, \mathrm{OH}$ ); ${ }^{13} \mathrm{C}$ NMR (DSMO- $\left.d_{6}\right) \delta 51.23,123.34,126.44$, $126.55,126.74,127.44,127.70,127.82,128.36,128.78,129.01$, $131.87,132.51,133.01,133.83,139.72,145.50$; MS (ESI) $m / z 325.1$ $[\mathrm{M}]^{+}$.

(4) 1-(4-Tolyl)-2-tosylethanone Oxime (4d). Yield (83\%); m.p. $168-170^{\circ} \mathrm{C}$; IR v $3069(\mathrm{OH}) \mathrm{cm}^{-1} ;{ }^{1} \mathrm{H}$ NMR $\left(\mathrm{CDCl}_{3}\right) \delta 2.29$ (s, 3H, $\mathrm{CH}_{3}$ ), 2.31 (s, 3H, $\left.\mathrm{CH}_{3}\right), 4.63\left(\mathrm{~s}, 2 \mathrm{H}, \mathrm{CH}_{2}\right), 7.09$ (d, $J=8.0 \mathrm{~Hz}, 2 \mathrm{H}, \mathrm{ArH}), 7.15(\mathrm{~d}, J=8.0 \mathrm{~Hz}, 2 \mathrm{H}, \mathrm{ArH}), 7.43$ (d, $J=8.5 \mathrm{~Hz}, 2 \mathrm{H}, \mathrm{ArH}), 7.62(\mathrm{~d}, J=8.5 \mathrm{~Hz}, 2 \mathrm{H}, \mathrm{ArH}), 11.90$ (s, $\mathrm{D}_{2} \mathrm{O}$ exchangeable, $\left.1 \mathrm{H}, \mathrm{OH}\right) ;{ }^{13} \mathrm{C} \mathrm{NMR}\left(\mathrm{CDCl}_{3}\right) \delta 21.33$ $\left(-\mathrm{CH}_{3}\right), 21.46\left(-\mathrm{CH}_{3}\right), 52.86\left(-\mathrm{CH}_{2}\right), 126.65,128.48,128.69$, $128.94,129.35,129.44,129.72,129.87,130.63,136.57,140.30$, 144.89, 148.10; MS (EI) m/z: $303[\mathrm{M}]^{+}$.

(5) 1-(Naphthalen-2-yl)-2-tosylethanone Oxime (4e). Yield (84\%); m.p. $158-160^{\circ} \mathrm{C}$; IR $v 3200(\mathrm{OH}) \mathrm{cm}^{-1}$; ${ }^{1} \mathrm{H}$ NMR $\left(\mathrm{CDCl}_{3}\right) \delta 2.21\left(\mathrm{~s}, 1 \mathrm{H}, \mathrm{CH}_{3}\right) 4.78\left(\mathrm{~s}, 2, \mathrm{CH}_{2}\right), 7.08(\mathrm{~d}, J=$ $8.5 \mathrm{~Hz}, 2 \mathrm{H}, \mathrm{ArH}), 7.42-7.45$ (m, 2H, ArH), 7.63 (d, $J=8.5 \mathrm{~Hz}$, 2H, ArH), 7.70-7.75 (m, 4H, ArH), 7.88 (s, 1H, ArH), 11.91 (s, $\mathrm{D}_{2} \mathrm{O}$ exchangeable, $\left.1 \mathrm{H}, \mathrm{OH}\right) ;{ }^{13} \mathrm{C}$ NMR $\left(\mathrm{CDCl}_{3}\right) \delta 21.51$ $\left(-\underline{C H}_{3}\right), 52.67\left(-\underline{C H}_{2}\right), 123.25,126.54,127.16,127.27,127.59$, $128.35,128.51,128.76,129.46,130.81,132.88,133.86,136.51$, 144.98, 148.08; MS (EI) $m / z 339[\mathrm{M}]^{+}$.

\subsubsection{Synthesis of Hydrazones $\mathbf{5 a}, \boldsymbol{b}$}

MWI Synthesis. A mixture of the appropriate sulfone 3 ( $1 \mathrm{mmol})$ and hydrazine hydrate $(99 \%)$ or phenyl hydrazine $(1 \mathrm{mmol})$ in ethanol $(5 \mathrm{~mL})$, acetic acid $(0.5 \mathrm{~mL})$ was added to a closed vessel in a microwave reactor. The closed vessel was irradiated with microwave at $100 \mathrm{~W}$ and $90^{\circ} \mathrm{C}$, with $200 \mathrm{psi}$ maximum pressure for $30 \mathrm{sec}$ (holding time). The vessel was cooled and the solid that formed was collected by filtration and washed with ethanol, dried, and finally recrystallized from EtOH to afford compounds 5a, b, respectively, in $86 \%$ and $94 \%$ yield, respectively.

Conventional Synthesis. A mixture of the appropriate sulfone 3 ( $1 \mathrm{mmol}$ ) and hydrazine hydrate or phenyl hydrazine $(1 \mathrm{mmol})$ in ethanol $(25 \mathrm{~mL})$, acetic acid $(0.5 \mathrm{~mL})$ was added. The reaction mixture was stirred for $6 \mathrm{~h}$. The precipitated product was filtered off, washed with ethanol, dried and finally recrystallization from ethanol afforded the corresponding hydrazones $5 \mathbf{a}, \mathbf{b}$, in $69 \%$ and $65 \%$ yield, respectively.

(1) (Z)-(1-(4-Chlorophenyl)-2-(phenylsulfonyl)ethylidene) hydrazine (5a). Yield (86\%); m.p. 151-153 ${ }^{\circ} \mathrm{C}$; IR v 3150-3400 $\left(\mathrm{NH}_{2}\right)$ $\mathrm{cm}^{-1} ;{ }^{1} \mathrm{H}$ NMR (DSMO- $\left.d_{6}\right) \delta 4.84\left(\mathrm{~s}, 2 \mathrm{H}, \mathrm{CH}_{2}\right), 7.22-7.35(\mathrm{~m}$, $3 \mathrm{H}, \mathrm{ArH}), 7.55-7.68,(\mathrm{~m}, 4 \mathrm{H}, \mathrm{ArH}), 7.70$ (s, $\mathrm{D}_{2} \mathrm{O}$ exchangeable, $1 \mathrm{H}, \mathrm{NH}_{2}$ ), 7.86-7.95 (m, 2H, ArH); ${ }^{13} \mathrm{C}$ NMR (DSMO- $\left.d_{6}\right) \delta$ 51.14, 126.75, 127.73, 127.96, 129.14, 129.81, 131.44, 133.97; MS (ESI) $m / z 308.8[\mathrm{M}]^{+}$.

(3) 1-(1-(Naphthalen-2-yl)-2-(phenylsulfonyl)ethylidene)-2phenylhydrazine (5b). Yield (94\%); m.p. 140-142 C; IR $v$ 
$3340(\mathrm{NH}) \mathrm{cm}^{-1} ;{ }^{1} \mathrm{H}$ NMR (DSMO- $\left.d_{6}\right) \delta 5.31\left(\mathrm{~s}, 2 \mathrm{H}, \mathrm{CH}_{2}\right)$, 6.83-6.86 (m, 1H, ArH), 7.19-7.21 (m, 2H, ArH), 7.26-7.28 (m, 2H, ArH), 7.48-7.49 (m, 5H, ArH), 7.80-7.93 (m, 5H, ArH), 8.01 (s, 1H, ArH), 8.05-8.07 (m, 1H, ArH), 9.86 (s, $\mathrm{D}_{2} \mathrm{O}$ exchangeable, $\left.1 \mathrm{H}, \mathrm{NH}\right) ;{ }^{13} \mathrm{C}$ NMR (DSMO- $\left.d_{6}\right) \delta 51.63$, $113.06,119.98,123.48,124.84,126.01,126.13,127.29,127.36$, $128.16,128.37,128.88,129.00,129.26,132.24,132.74,133.89$, 134.93, 139.36, 144.64; MS (ESI) $m / z 400.1[\mathrm{M}]^{+}$.

\subsubsection{Synthesis of Olefins $7 \boldsymbol{a}-\boldsymbol{d}$}

MWI Synthesis. To a mixture of the sulfone $3(1 \mathrm{mmol})$ and the appropriate aldehyde $(1 \mathrm{mmol})$ in ethanol $(30 \mathrm{~mL})$, piperidine $(0.5 \mathrm{~mL})$ was added to a closed vessel in a microwave reactor. The closed vessel was irradiated with microwave at $100 \mathrm{~W}$ and $90^{\circ} \mathrm{C}$, with 200 psi maximum pressure for $3 \mathrm{~min}$ (holding time). The vessel was then left to cool. The precipitated product was filtered off and purified by recrystallization from ethanol to afford the corresponding olefins $7 \mathbf{a}-\mathbf{d}$ in $77 \%-85 \%$ yields.

Conventional Synthesis. To a mixture of the sulfone $3(1 \mathrm{mmol})$ and the appropriate aldehyde $(1 \mathrm{mmol})$ in ethanol $(30 \mathrm{~mL})$, piperidine $(0.5 \mathrm{~mL})$ was added. The reaction mixture was refluxed for $5 \mathrm{~h}$ and then left to cool. The precipitated product was filtered off and purified by recrystallization from ethanol to afford $7 \mathbf{a}-\mathbf{d}$ in $42 \%-62 \%$ yields.

(1) (E)-3-(4-Chlorophenyl)-1-phenyl-2-tosylprop-2-en-1-one (7a). Yield (62\%); m.p. 198-200 ${ }^{\circ} \mathrm{C}$; IR $v 1676(\mathrm{C}=\mathrm{O}) \mathrm{cm}^{-1} ;{ }^{1} \mathrm{H}$ NMR $\left(\mathrm{CDCl}_{3}\right) \delta 2.34\left(\mathrm{~s}, 3 \mathrm{H}, \mathrm{CH}_{3}\right), 6.72-7.10(\mathrm{~m}, 5 \mathrm{H}, \mathrm{ArH}), 7.22-$ $7.93(\mathrm{~m}, 8 \mathrm{H}, \mathrm{ArH}), 8.42(\mathrm{~s}, 1 \mathrm{H},=\mathrm{CH}) ;{ }^{13} \mathrm{C} \mathrm{NMR}\left(\mathrm{CDCl}_{3}\right) \delta$ $21.71\left(-\mathrm{CH}_{3}\right), 127.76,128.00,128.63,128.73,128.84,129.18$, $129.34,129.47,129.84,130.00,130.91,134.31,135.81,145.36$, 190.83; MS (EI) $m / z 396[\mathrm{M}]^{+}$.

(2) (E)-1,3-Bis(4-methoxyphenyl)-2-tosylprop-2-en-1-one (7b). Yield (42\%); m.p. $188-190^{\circ} \mathrm{C}$; IR $v 1667(\mathrm{C}=\mathrm{O}) \mathrm{cm}^{-1}$; ${ }^{1} \mathrm{H}$ NMR $\left(\mathrm{DSMO}-d_{6}\right) \delta 2.41\left(\mathrm{~s}, 3 \mathrm{H},-\mathrm{CH}_{3}\right), 3.82\left(\mathrm{~s}, 3 \mathrm{H}, \mathrm{OCH}_{3}\right), 3.89$ (s, $\left.3 \mathrm{H},-\mathrm{OCH}_{3}\right), 6.88(\mathrm{~d}, J=8.5 \mathrm{~Hz}, 2 \mathrm{H}, \mathrm{ArH}), 7.14(\mathrm{~d}, J=8.5 \mathrm{~Hz}$, $2 \mathrm{H}, \mathrm{ArH}), 7.32(\mathrm{~d}, J=9.0 \mathrm{~Hz}, 2 \mathrm{H}, \mathrm{ArH}), 7.71(\mathrm{~d}, J=8.0 \mathrm{~Hz}, 2 \mathrm{H}$, $\operatorname{ArH}), 7.88(\mathrm{~d}, J=8.5 \mathrm{~Hz}, 2 \mathrm{H}, \mathrm{ArHs}), 7.91(\mathrm{~d}, J=9.0 \mathrm{~Hz}, 2 \mathrm{H}$, $\mathrm{ArH}), 8.33(\mathrm{~s}, 1 \mathrm{H},=\mathrm{CH})$; MS (EI) $\mathrm{m} / z 422[\mathrm{M}]^{+}$.

(3) (E)-3-(4-Chlorophenyl)-1-(4-fluorophenyl)-2-tosylprop-2en-1-one (7c). Yield (55\%); m.p. 218-220 ${ }^{\circ} \mathrm{C}$; IR $v 1673(\mathrm{C}=\mathrm{O})$ $\mathrm{cm}^{-1} ;{ }^{1} \mathrm{H}$ NMR $\left(\mathrm{CDCl}_{3}\right) \delta 2.38\left(\mathrm{~s}, 3 \mathrm{H}, \mathrm{CH}_{3}\right), 7.07-7.12(\mathrm{~m}$, $3 \mathrm{H}, \mathrm{ArH}$ ), 7.26-7.28 (m, 2H, ArH), 7.67-7.69 (m, 3H, ArH), 7.75-7.77 (m, 2H, ArH), 7.91-7.95 (m, 2H, ArH), 8.60 (s, $1 \mathrm{H},=\mathrm{CH}) ;{ }^{13} \mathrm{C} \mathrm{NMR}\left(\mathrm{CDCl}_{3}\right) \delta 20.69\left(\mathrm{CH}_{3}\right), 115.32,127.53$, $127.69,128.29,128.45,128.86,129.89,130.23,131.18,131.26$, $131.61,131.69,133.71,134.67,138.36,139.26,139.94,144.09$, 144.46, 189.81; MS (EI) $m / z 414[\mathrm{M}]^{+}$.

(4) (E)-1,3-Bis(4-chlorophenyl)-2-tosylprop-2-en-1-one (7d). Yield (57\%); m.p. $235-237^{\circ} \mathrm{C}$; IR $v 1674(\mathrm{C}=\mathrm{O}) \mathrm{cm}^{-1} ;{ }^{1} \mathrm{H}$ $\operatorname{NMR}\left(\mathrm{CDCl}_{3}\right) \delta 2.37\left(\mathrm{~s}, 3 \mathrm{H}, \mathrm{CH}_{3}\right), 7.27(\mathrm{~d}, J=8.5 \mathrm{~Hz}, 2 \mathrm{H}$, ArHs), 7.40 (d, $J=8.5 \mathrm{~Hz}, 2 \mathrm{H}, \mathrm{ArH}), 7.45(\mathrm{~d}, J=8.5 \mathrm{~Hz}, 2 \mathrm{H}$, ArH), 7.67 (d, $J=8.5 \mathrm{~Hz}, 2 \mathrm{H}, \mathrm{ArH}), 7.78(\mathrm{~d}, J=8.5 \mathrm{~Hz}, 2 \mathrm{H}$,
ArH), $7.84(\mathrm{~d}, J=8.5 \mathrm{~Hz}, 2 \mathrm{H}, \mathrm{ArH}), 8.50(\mathrm{~s}, 1 \mathrm{H},=\mathrm{CH}) ;{ }^{13} \mathrm{C}$ $\operatorname{NMR}\left(\mathrm{CDCl}_{3}\right) \delta 20.70\left(\mathrm{CH}_{3}\right), 127.54,128.19,128.45,129.76$, 129.89, 133.09, 133.71, 139.95, 189.80; MS (EI) $\mathrm{m} / z 433[\mathrm{M}]^{+}$.

\subsection{X-Ray Crystallography}

2.2.1. General. Single crystals were obtained by slow evaporation from ethanol. A good crystal with a suitable size was selected for X-ray diffraction analysis. Data were collected on a Bruker D8 Venture area diffractometer equipped with graphite monochromatic $\mathrm{MoK} \backslash \alpha$ radiation $(\lambda=0.71073 \AA)$ at $100 \mathrm{~K}$. Cell refinement and data reduction were done by Bruker SAINT (Bruker, 2009); program used to solve structure and refine structure is SHELXS-97 [24]. The final refinement was performed by full-matrix least-squares techniques with anisotropic thermal data for nonhydrogen atoms on $F^{2}$. All the hydrogen atoms were placed in calculated positions and constrained to ride on their parent atoms. Multiscan absorption correction was applied by use of SADABS software (Bruker, 2009). The crystal structure of compound 5 a contains one molecule in the asymmetric unit.

2.2.2. Crystal Data of 5 a. Molecular formula $\mathrm{C}_{14} \mathrm{H}_{13} \mathrm{ClN}_{2} \mathrm{O}_{2} \mathrm{~S}$, Formula weight: 308.77 , Triclinic, $P-1, a=5.7735$ (2) $\AA, b=$ 9.3224 (3) $\AA, c=13.1696$ (5) $\AA, \alpha=76.411(1)^{\circ}, \beta=89.571$ (1) ${ }^{\circ}$, $\gamma=79.9380(9)^{\circ}, V=677.97(4) \AA^{3}$, and $D_{\text {calc }}=1.513 \mathrm{Mg} \mathrm{m}^{-3}$. A total of 20423 reflections were measured, of which 2771 were independent. $R_{\text {int }}=0.021$, Dataset $(\mathrm{h} ; \mathrm{k} ; \mathrm{l})=-7,7 ;-11$, $11 ;-16,16$. Refinement of $F^{2}$, against all reflections, led to $R$ $\left[F^{2}>2 \sigma\left(F^{2}\right)\right]=0.026, w R\left(F^{2}\right)=0.178, S=1.00$. The labeled displacement ellipsoid plot of this molecule showing the three intramolecular interactions is shown in Figure 1.

\section{Results and Discussion}

3.1. Chemistry. 1-Aryl-2-(arylsulfonyl)ethanones 3 were synthesized by the reaction of bromo-1-arylethanones 1 with sodium (aryl)sulfinate $\mathbf{2}$ (Scheme 1) according to the reported method [23]. Sulfones 3 were reacted with hydroxyl amine in the presence of sodium acetate to afford oximes $4 \mathbf{a}-\mathbf{e}$, respectively (Scheme 1). The latter reaction was performed in ethanol under microwave irradiation $\left(100 \mathrm{~W}, 90^{\circ} \mathrm{C}\right)$ for $2 \mathrm{~min}$ to give oximes $4 \mathbf{a}-\mathbf{e}$ in good yield ( $80-88 \%)$. However, oximes $4 \mathbf{a}-\mathbf{e}$ were also prepared conventionally in refluxing ethanol for $1 \mathrm{~h}$ in $54-70 \%$ yield.

The IR spectra of oximes $4 \mathbf{a}-\mathbf{e}$ showed the appearance of $\mathrm{OH}$ absorption band in $3069-3270 \mathrm{~cm}^{-1}$ region, whereas their ${ }^{1} \mathrm{H}$ NMR revealed the singlet signal of methylene protons in the region $\delta 4.27-5.09$. Moreover, ${ }^{13} \mathrm{C}$ NMR of compounds $4 \mathrm{a}-\mathbf{e}$ showed the signal of methylene carbon in the region $\delta 51.23-55.38$ in addition to the signal of $S P^{2}$ carbon of $-\mathrm{C}=\mathrm{N}-$ group in the region $\delta 145.50-148.10$.

Furthermore, the reaction of sulfones 3 with hydrazine or phenylhydrazine in ethanol at $90^{\circ} \mathrm{C}$ under microwave irradiation with power $100 \mathrm{~W}$ for $30 \mathrm{sec}$ gave hydrazones $\mathbf{5 a}$, b in $86 \%$ and $94 \%$ yield, respectively (Scheme 1). However, the conventional synthesis of hydrazones $\mathbf{5 a}, \mathbf{b}$ at ambient temperature afforded hydrazones $\mathbf{5 a}, \mathbf{b}$ in lower yields. 

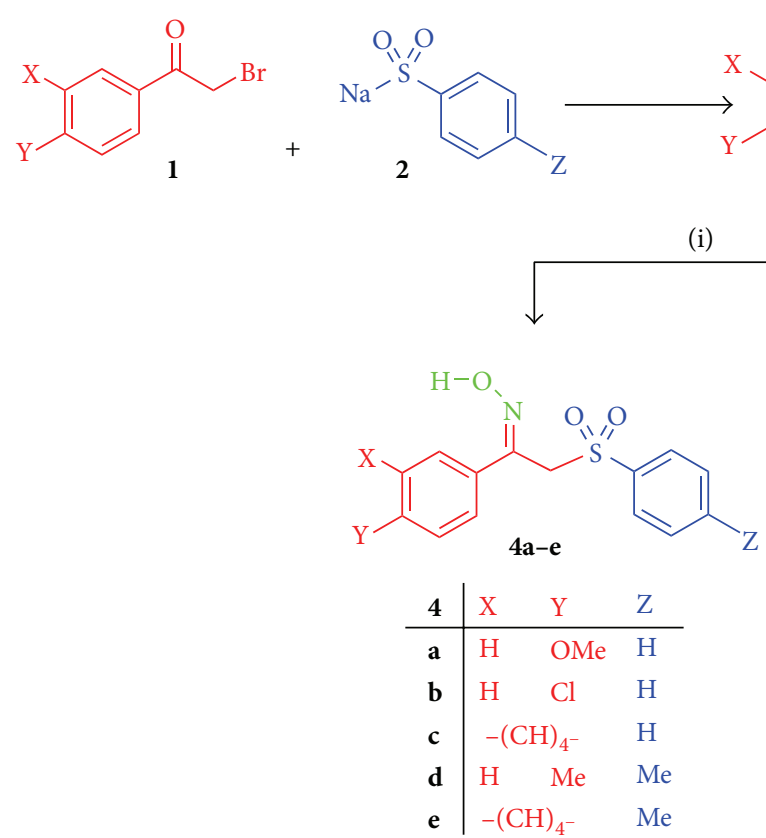

(ii)

Scheme 1: Synthesis of oximes $\mathbf{4 a - e}$ and hydrazones $\mathbf{5 a}$, b. Reagents and conditions: (i) $\mathrm{NH}_{2}-\mathrm{OH} / \mathrm{AcONa} / \mathrm{EtOH}, \mathrm{MWI}, 100 \mathrm{~W}, 90^{\circ} \mathrm{C}$, 2 min, $80-88 \%$ yield. (ii) $\mathrm{NH}_{2}-\mathrm{NH}_{2}$ (99\%) or $\mathrm{NH}_{2}-\mathrm{NHPh} / \mathrm{EtOH} / \mathrm{AcOH}$ (catalytic amount), $\mathrm{MWI}, 100 \mathrm{~W}, 90^{\circ} \mathrm{C}, 30 \mathrm{sec}, 86 \%$ and $94 \%$ yield, respectively.

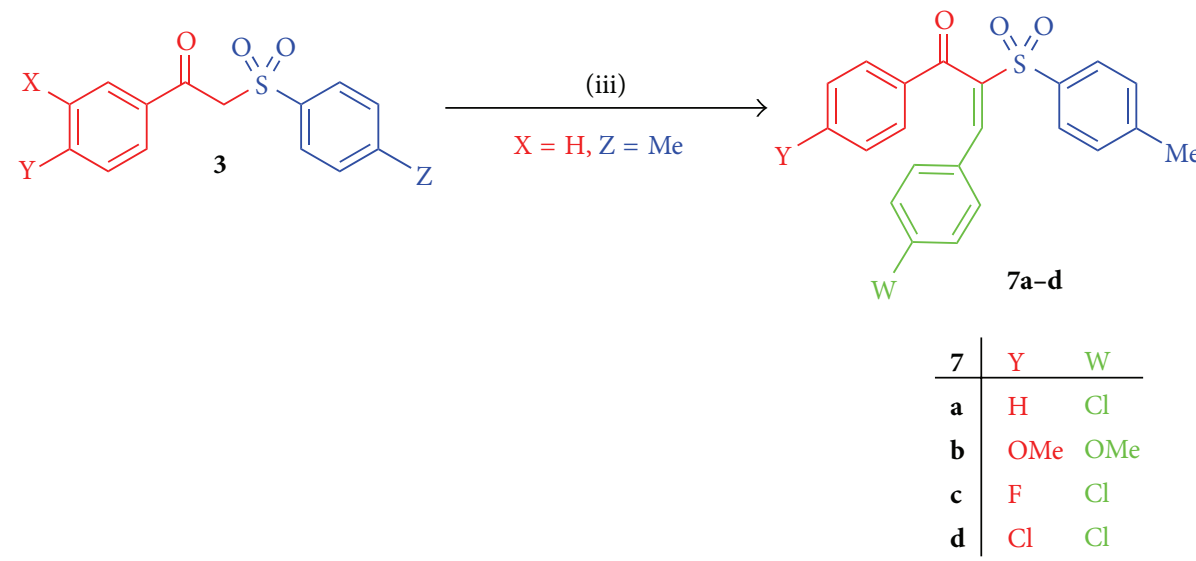

Scheme 2: Synthesis of olefins 7a-d. (iii) Ar-CHO 6a, b/EtOH/piperidine (catalytic amount)/MWI, $100 \mathrm{~W}, 90^{\circ} \mathrm{C}, 3 \mathrm{~min}, 77-85 \%$ yield.

The ${ }^{1} \mathrm{H}$ NMR of $\mathbf{5 a}$ showed the $\mathrm{D}_{2} \mathrm{O}$ exchangeable singlet signal of $\mathrm{NH}_{2}$ at $\delta 7.70$ whereas ${ }^{1} \mathrm{H}$ NMR of phenyl hydraone $\mathbf{5 b}$ exhibited the signal of the $\mathrm{NH}$ group at $\delta 9.86$. The $\mathrm{X}$ ray single crystal analysis of compound $\mathbf{5 a}$ gave the relative configuration for the 3D structure (Figure 1) [25].

Next, the reaction of sulfones 3 with 4-chlorobenzaldehyde $\mathbf{6 a}$ or 4 -anisaldehyde $\mathbf{6 b}$, in the presence of piperidine under microwave irradiation $\left(100 \mathrm{~W}, 90^{\circ} \mathrm{C}\right)$ for $3 \mathrm{~min}$, afforded the corresponding olefins 7a-d, respectively, in 77$85 \%$ yields (Scheme 2 ). The time requested to complete the latter reaction in conventional synthesis is $5 \mathrm{~h}$ with moderate yields. The structure of the latter compounds was confirmed on the basis of their spectral data; for example, their IR spectra revealed the absorption band of carbonyl function in the region $1665-1676 \mathrm{~cm}^{-1}$ while their ${ }^{1} \mathrm{H}$ NMR exhibited the signal of $-\mathrm{CH}=$ proton in the region $\delta 8.33-8.60$.

3.2. Interpretation of the $X$-Ray Structure. The asymmetric unit of compound $\mathbf{5 a}, \mathrm{C}_{14} \mathrm{H}_{13} \mathrm{ClN}_{2} \mathrm{O}_{2} \mathrm{~S}$, contains one molecule with $Z$ configuration about the $\mathrm{C} 7=\mathrm{N} 1$ double bond (Figure 1). The $Z$ configuration of $\mathbf{5 a}$ is stabilized with intramolecular hydrogen $\mathrm{N} 2-\mathrm{H} 1 \cdots \mathrm{O} 2$ (Table 2). The single bond N1-N2 is clearly characterized by the distance of 1.3496 (16) $\AA$. The double bond of $\mathrm{C} 7=\mathrm{N} 1$ is characterized by the distance of 1.2933 (16) $\AA$. The dihedral angel between the two benzene rings is $45.63(5)^{\circ}$. The packing in the crystal structure is stabilized by intermolecular interactions N2$\mathrm{H} 2 \cdots \mathrm{N} 1$ and $\mathrm{N} 2-\mathrm{H} 1 \cdots \mathrm{O} 1$ which links the molecules into 
TABLE 1: Selected geometric parameters $\left(\AA,^{\circ}\right)$ of $\mathbf{5 a}$.

\begin{tabular}{|c|c|c|c|}
\hline \multicolumn{4}{|c|}{ Bond distance } \\
\hline Cl1-C3 & $1.7437(13)$ & S1-C9 & $1.7650(12)$ \\
\hline $\mathrm{S} 1-\mathrm{O} 1$ & $1.4425(10)$ & N1-N2 & $1.3496(16)$ \\
\hline $\mathrm{S} 1-\mathrm{O} 2$ & $1.4459(9)$ & N1-C7 & $1.2933(16)$ \\
\hline S1-C8 & $1.7872(12)$ & & \\
\hline \multicolumn{4}{|c|}{ Bond angle } \\
\hline $\mathrm{O} 1-\mathrm{S} 1-\mathrm{O} 2$ & $118.46(6)$ & Cl1-C3-C4 & $120.08(9)$ \\
\hline O1-S1-C8 & $107.63(6)$ & Cl1-C3-C2 & $119.06(10)$ \\
\hline O1-S1-C9 & $107.95(6)$ & N1-C7-C8 & $122.14(11)$ \\
\hline $\mathrm{O} 2-\mathrm{S} 1-\mathrm{C} 8$ & $108.57(6)$ & N1-C7-C6 & $116.63(11)$ \\
\hline $\mathrm{O} 2-\mathrm{S} 1-\mathrm{C} 9$ & $108.17(5)$ & $\mathrm{S} 1-\mathrm{C} 8-\mathrm{C} 7$ & $114.33(8)$ \\
\hline C8-S1-C9 & $105.32(6)$ & S1-C9-C10 & $119.78(9)$ \\
\hline N2-N1-C7 & $120.74(11)$ & S1-C9-C14 & $118.44(9)$ \\
\hline \multicolumn{4}{|c|}{ Torsion angle } \\
\hline O1-S1-C8-C7 & $-175.58(8)$ & $\mathrm{C} 1-\mathrm{C} 2-\mathrm{C} 3-\mathrm{Cl} 1$ & $178.98(10)$ \\
\hline $\mathrm{O} 2-\mathrm{S} 1-\mathrm{C} 8-\mathrm{C} 7$ & $55.07(10)$ & N2-N1-C7-C6 & $178.36(11)$ \\
\hline C9-S1- C8-C7 & $-60.60(10)$ & N2-N1-C7-C8 & $2.81(18)$ \\
\hline C8-S1-C9-C10 & $101.87(11)$ & C6-C7-C8-S1 & $-87.39(13)$ \\
\hline
\end{tabular}

TABle 2: Hydrogen bond geometry $\left(\AA ̊{ }^{\circ}\right)$ of $\mathbf{5 a}$.

\begin{tabular}{lcccc}
\hline $\mathrm{D}-\mathrm{H} \cdots \mathrm{A}$ & $\mathrm{D}-\mathrm{H}$ & $\mathrm{H} \cdots \mathrm{A}$ & $\mathrm{D} \cdots \mathrm{A}$ & $\mathrm{D}-\mathrm{H} \cdots \mathrm{A}$ \\
\hline $\mathrm{N} 2-\mathrm{H} 1 \cdots \mathrm{O} 2$ & $0.847(19)$ & $2.413(19)$ & $3.0753(15)$ & $135.6(17)$ \\
\hline $\mathrm{N} 2-\mathrm{H} 2 \cdots \mathrm{N} 1 \mathrm{i}$ & $0.887(18)$ & $2.225(19)$ & $3.0383(16)$ & $152.4(16)$ \\
$\mathrm{N} 2-\mathrm{H} 1 \cdots \mathrm{O} 1 \mathrm{ii}$ & $0.847(19)$ & $2.368(19)$ & $2.9687(15)$ & $128.3(16)$ \\
\hline
\end{tabular}

Symmetry codes: (i) $-x+1,-y+1,-z+1$; (ii) $-x+1,-y,-z+1$.

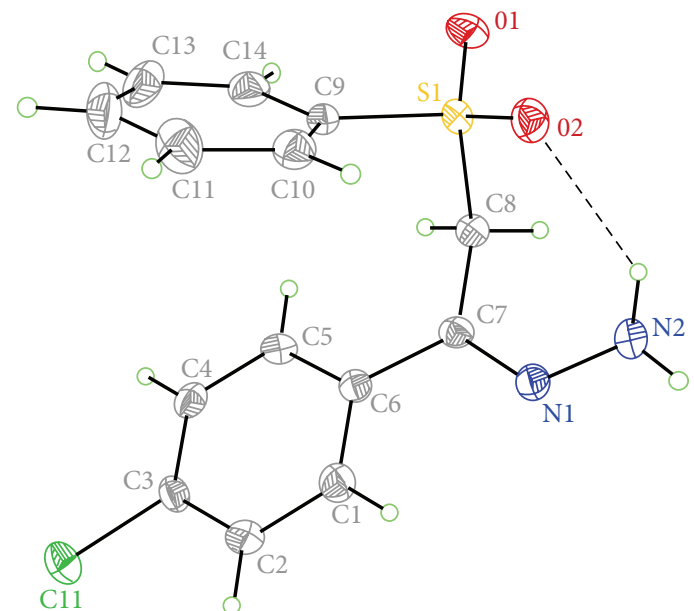

FIGURE 1: ORTEP diagram of 5a, $40 \%$ probability ellipsoid, showing intramolecular hydrogen bond N2-H1 ․ O2 (dashed line).

two parallel chains and forming a three-dimensional network (Figure 2). The selected geometric parameters and hydrogen bonds geometry for the crystal of $\mathbf{5 a}$ were shown in Tables 1 and 2 , respectively.

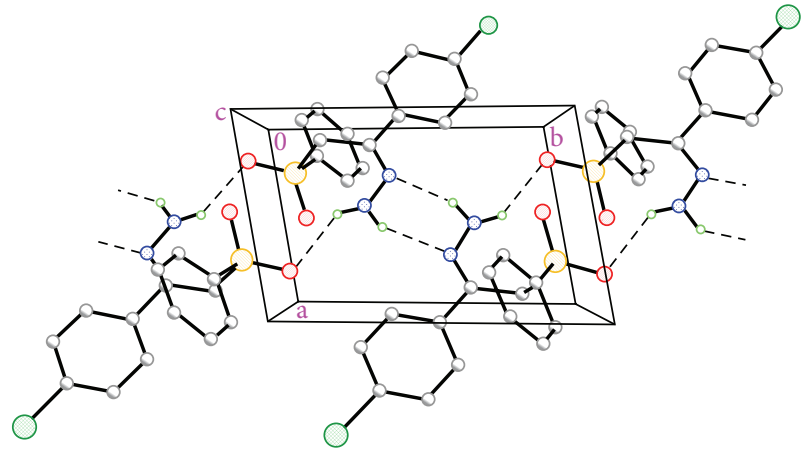

FIGURE 2: Portion of the crystal packing of $\mathbf{5 a}$. Dashed lines indicate $\mathrm{N} 2-\mathrm{H} 2 \cdots \mathrm{N} 1$ and $\mathrm{N} 2-\mathrm{H} 1 \cdots \mathrm{O} 1$ intermolecular hydrogen bonds. $\mathrm{H}$ atoms not involved in hydrogen bonding are omitted for clarity.

\section{Conclusion}

In conclusion, new series of oximes $\mathbf{4 a - e}$, hydrazones $\mathbf{5 a}$, $\mathbf{b}$, and chalcones $7 \mathbf{a}-\mathbf{d}$ were prepared using MWI which is more efficient in the synthesis of these compounds with shortening the reaction time and increasing their yields. The $\mathrm{X}$-ray analysis of $\mathbf{5 a}$ gives the relative configuration for the $3 \mathrm{D}$ structure. 


\section{Conflict of Interests}

The authors declare that there is no conflict of interests regarding the publication of this paper.

\section{Acknowledgment}

The authors would like to extend their sincere appreciation to the Deanship of Scientific Research at King Saud University for its funding of this research through the Research Group Project no. RGP-VPP-321.

\section{References}

[1] N. K. Konduru, S. Dey, M. Sajid, M. Owais, and N. Ahmed, "Synthesis and antibacterial and antifungal evaluation of some chalcone based sulfones and bisulfones," European Journal of Medicinal Chemistry, vol. 59, pp. 23-30, 2013.

[2] J. N. Dominguez, C. Leon, J. Rodrigues, N. G. de Dominguez, J. Gut, and P. J. Rosenthal, "Synthesis of chlorovinyl sulfones as structural analogs of chalcones and their antiplasmodial activities," European Journal of Medicinal Chemistry, vol. 44, no. 4, pp. 1457-1462, 2009.

[3] M. Y. Chang, Y. C. Chen, S. Y. Lin, and C. K. Chan, "One-pot synthesis of sulfonyl $(E)$-stilbenes by nitrobenzene-mediated dimerizative desulfonation of benzylic sulfones," Tetrahedron, vol. 70, no. 9, pp. 1740-1747, 2014.

[4] B. Sreedhar, M. A. Reddy, and P. S. Reddy, "A new protocol for the $\beta$-sulfonation of $\alpha, \beta$-unsaturated carbonyl compounds with sodium $p$-toluenesulfinate employs $\mathrm{FeCl}$ as catalyst and TMSCl as additive," Synlett, vol. 13, no. 73, pp. 1949-1952, 2008.

[5] Y. M. Markitanov, V. M. Timoshenko, and Y. G. Shermolovich, " $\beta$-Keto sulfones: Preparation and application in organic synthesis," Journal of Sulfur Chemistry, vol. 35, no. 2, pp. 188-236, 2014.

[6] N. Samakkanad, P. Katrun, and T. Techajaroonjit, "A combination of o- iodoxybenzoic acid and iodine mediates a direct synthesis of $\beta$ - keto sulfones from alkenes and arenesulfinates in good yields in a one-pot reaction," Synthesis, vol. 44, no. 11, pp. 1693-1699, 2012.

[7] R. D. Savka, N. T. Pohodylo, and M. D. Obushak, "Effective method of $\beta$-keto sulfones synthesis," Russian Journal of Organic Chemistry, vol. 50, no. 2, pp. 296-297, 2014.

[8] G. Zhao, J.-B. Hu, Z.-S. Qian, and W.-X. Yin, "Enantioselective reduction of $\beta$-keto sulfones using the $\mathrm{NaBH}_{4} / \mathrm{Me}_{3} \mathrm{SiCl}$ system catalyzed by polymer-supported chiral sulfonamide," Tetrahedron: Asymmetry, vol. 13, no. 19, pp. 2095-2098, 2002.

[9] V. S. Rawat, P. L. M. Reddy, and B. Sreedhar, "Chemoselective one-pot synthesis of $\beta$-keto sulfones from ketones," RSC Advances, vol. 4, no. 10, pp. 5165-5168, 2014.

[10] C. Curti, M. Laget, A. O. Carle, A. Gellis, and P. Vanelle, "Rapid synthesis of sulfone derivatives as potential anti-infectious agents," European Journal of Medicinal Chemistry, vol. 42, no. 6, pp. 880-884, 2007.

[11] J. Xiang, M. Ipek, V. Suri et al., " $\beta$-Keto sulfones as inhibitors of $11 \beta$-hydroxysteroid dehydrogenase type I and the mechanism of action," Bioorganic and Medicinal Chemistry, vol. 15, no. 13, pp. 4396-4405, 2007.

[12] J. Xiang, M. Ipek, V. Suri et al., "Synthesis and biological evaluation of sulfonamidooxazoles and $\beta$-keto sulfones: Selective inhibitors of $11 \beta$-hydroxysteroid dehydrogenase type I,"
Bioorganic and Medicinal Chemistry Letters, vol. 15, no. 11, pp. 2865-2869, 2005.

[13] M. R. Shaaban, T. S. Saleh, A. S. Mayhoub, and A. M. Farag, "Single step synthesis of new fused pyrimidine derivatives and their evaluation as potent Aurora-A kinase inhibitors," European Journal of Medicinal Chemistry, vol. 46, no. 9, pp. 3690-3695, 2011.

[14] H. A. Abdel-Aziz, K. A. Al-Rashood, K. E. H. Eltahir, and G. M. Suddek, "Synthesis of N-benzenesulfonamide-1H-pyrazoles bearing arylsulfonyl moiety: novel celecoxib analogs as potent anti-inflammatory agents," European Journal of Medicinal Chemistry, vol. 80, pp. 416-422, 2014.

[15] S. Tu, Y. Q. Xie, S. Z. Gui et al., "Synthesis and fungicidal activities of novel benzothiophene-substituted oxime ether strobilurins," Bioorganic and Medicinal Chemistry Letters, vol. 24, no. 9, pp. 2173-2176, 2014.

[16] A. Karakurt, M. A. Alagöz, B. Sayoğlu, Ü. Çalş, and S. Dalkara, "Synthesis of some novel 1-(2-naphthyl)-2-(imidazol1-yl)ethanone oxime ester derivatives and evaluation of their anticonvulsant activity," European Journal of Medicinal Chemistry, vol. 57, pp. 275-282, 2012.

[17] R. Odžak, M. Skočibušić, and A. Maravić, "Synthesis and antimicrobial profile of $N$-substituted imidazolium oximes and their monoquaternary salts against multidrug resistant bacteria," Bioorganic and Medicinal Chemistry, vol. 21, no. 23, pp. 7499-7506, 2013.

[18] T. Moreira Osório, F. Delle Monache, L. Domeneghini Chiaradia et al., "Antibacterial activity of chalcones, hydrazones and oxadiazoles against methicillin-resistant Staphylococcus aureus," Bioorganic and Medicinal Chemistry Letters, vol. 22, no. 1, pp. 225-230, 2012.

[19] A. M. Pieczonka, A. Strzelczyk, B. Sadowska, G. Mlostoń, and P. Staczek, "Synthesis and evaluation of antimicrobial activity of hydrazones derived from 3-oxido- $1 \mathrm{H}$-imidazole-4carbohydrazides," European Journal of Medicinal Chemistry, vol. 64, pp. 389-395, 2013.

[20] H. A. Abdel-Aziz, T. Elsaman, A. Al-Dhfyan, M. I. Attia, K. A. Al-Rashood, and A.-R. M. Al-Obaid, "Synthesis and anticancer potential of certain novel 2-oxo- $N^{\prime}$-(2-oxoindolin- 3-ylidene)$2 \mathrm{H}$-chromene-3-carbohydrazides," European Journal of Medicinal Chemistry, vol. 70, pp. 358-363, 2013.

[21] H. A. Abdel-Aziz, P. Ahmad, A. Kadi, K. A. Al-Rashood, H. A. Ghabbour, and H.-K. Fun, "Unexpected ring-opening of 3 -aroylbenzo[b]furans at room temperature: a new route for the construction of phenol-substituted pyrazoles," Tetrahedron Letters, vol. 54, no. 26, pp. 3424-3426, 2013.

[22] H. A. Abdel-Aziz, H. S. A. El-Zahabi, and K. M. Dawood, "Regioselective synthesis and in-vitro anti-tumor activity of 1,3,4-triaryl-5- $N$-arylpyrazole-carboxamides," European Journal of Medicinal Chemistry, vol. 45, no. 6, pp. 2427-2432, 2010.

[23] P. Sunitha, K. S. Kumar, B. R. Rao, and G. Venkateshwarlu, "Microwave assisted efficient synthesis of $\beta$-keto-sulfones in aqueous medium," Green Chemistry Letters and Reviews, vol. 1, no. 3, pp. 179-183, 2008.

[24] G. M. Sheldrick, "A short history of SHELX," Acta Crystallographica Section A: Foundations of Crystallography, vol. 64, no. 1, pp. 112-122, 2007.

[25] Crystallographic data for the structure $5 \mathrm{a}$ has been deposited with the Cambridge Crystallographic Data Center (CCDC) under the numbers CCDC 990377. Copies of the data can be obtained, free of charge, with Cambrige, UK, http://www.ccdc .cam.ac.uk. 

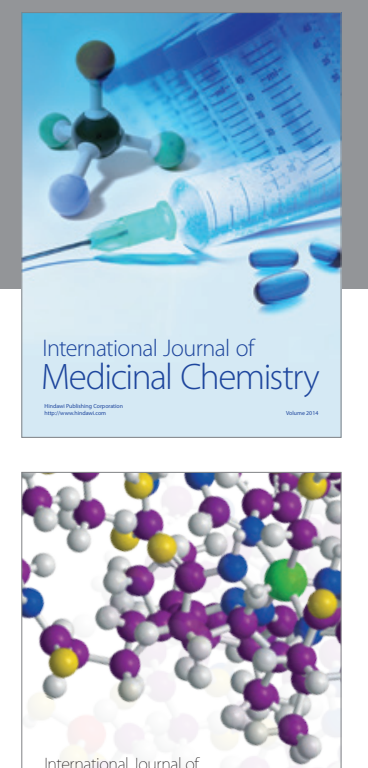

\section{Carbohydrate} Chemistry

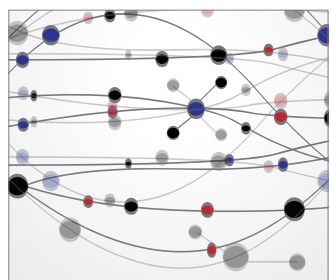

The Scientific World Journal
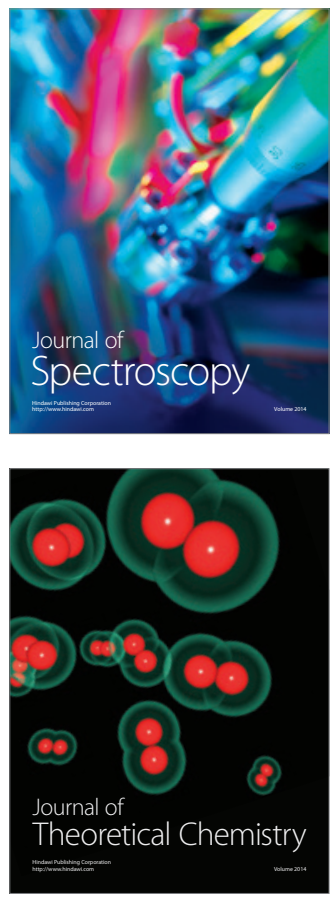
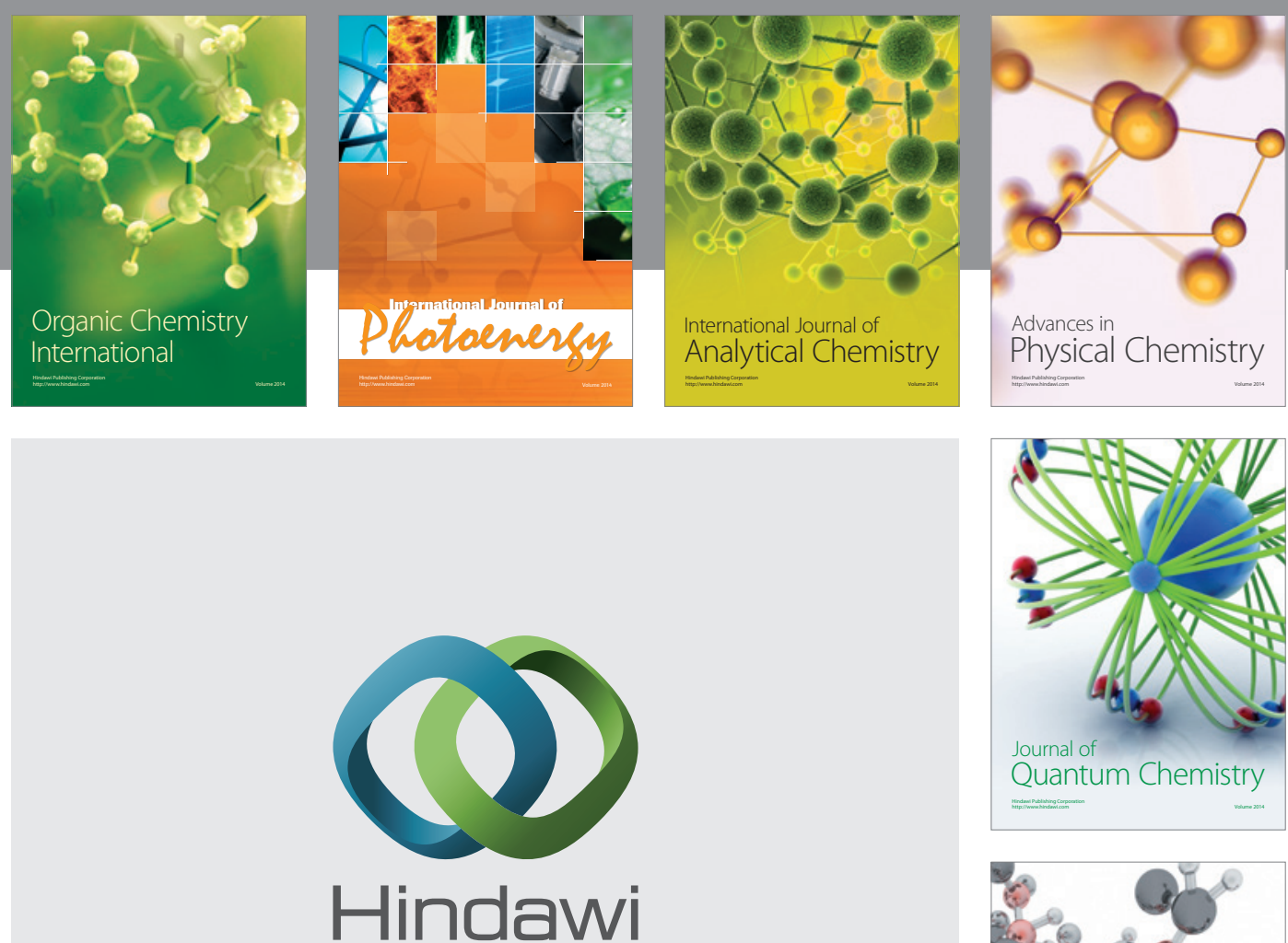

Submit your manuscripts at

http://www.hindawi.com

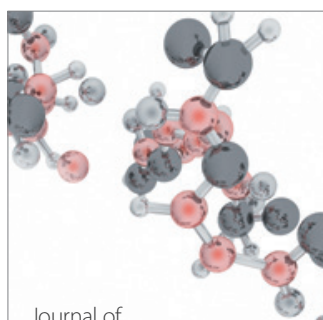

Analytical Methods

in Chemistry

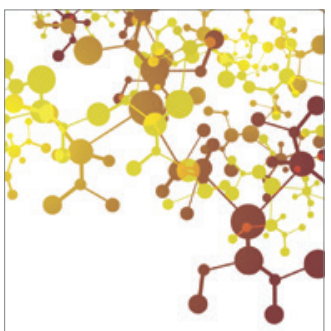

Journal of

Applied Chemistry

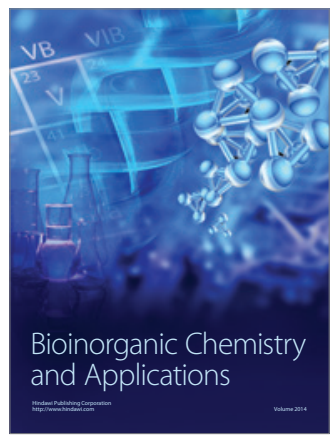

Inorganic Chemistry
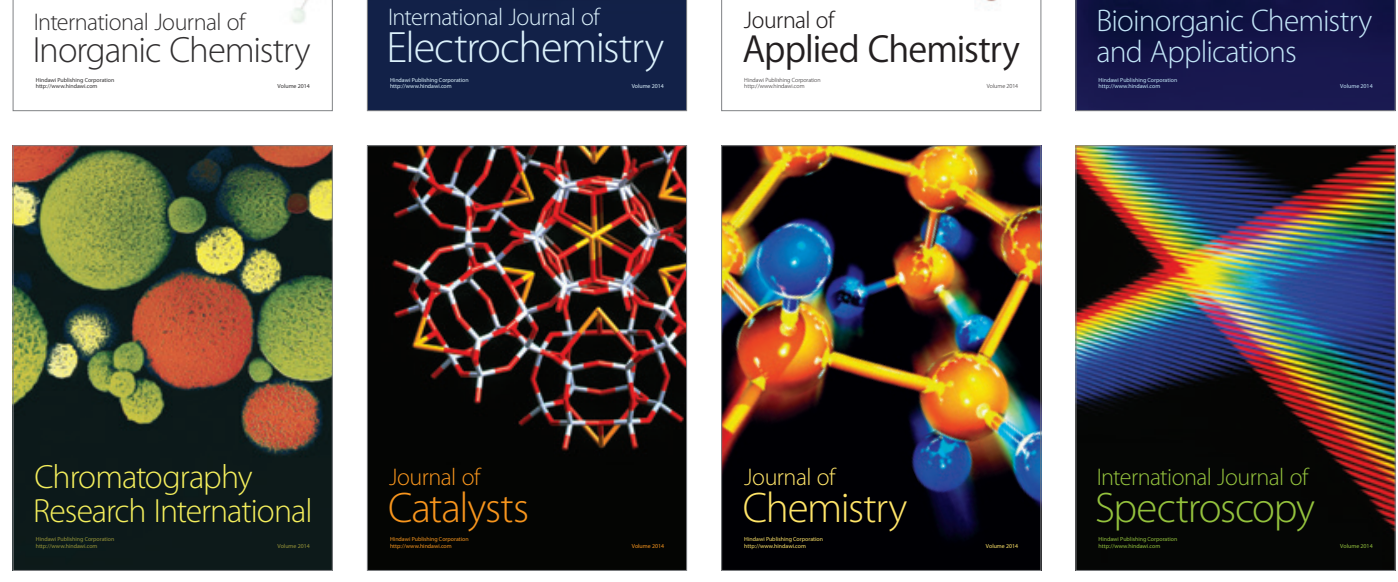